"Information technology practices in the Jordanian retail sector: Employee and customer perspective"

\begin{tabular}{|c|c|}
\hline AUTHORS & Khalid M. Alomari (iD) \\
\hline ARTICLE INFO & $\begin{array}{l}\text { Khalid M. Alomari (2022). Information technology practices in the Jordanian retail } \\
\text { sector: Employee and customer perspective. Innovative Marketing , 18(1), 38-48. } \\
\text { doi:10.21511/im.18(1).2022.04 }\end{array}$ \\
\hline DOI & http://dx.doi.org/10.21511/im.18(1).2022.04 \\
\hline RELEASED ON & Tuesday, 08 February 2022 \\
\hline RECEIVED ON & Wednesday, 10 November 2021 \\
\hline \multirow[t]{2}{*}{ ACCEPTED ON } & Tuesday, 25 January 2022 \\
\hline & $(\mathrm{cc}) \overline{\mathrm{EY}}$ \\
\hline LICENSE & $\begin{array}{l}\text { This work is licensed under a Creative Commons Attribution } 4.0 \text { International } \\
\text { License }\end{array}$ \\
\hline JOURNAL & "Innovative Marketing " \\
\hline ISSN PRINT & $1814-2427$ \\
\hline ISSN ONLINE & $1816-6326$ \\
\hline PUBLISHER & LLC "Consulting Publishing Company "Business Perspectives" \\
\hline FOUNDER & LLC "Consulting Publishing Company "Business Perspectives" \\
\hline & 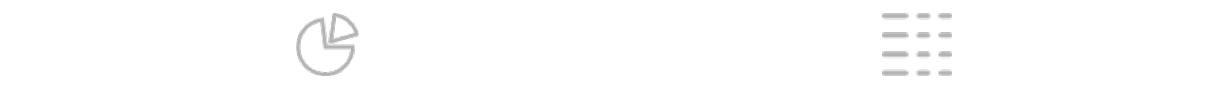 \\
\hline NUMBER OF REFERENCES & NUMBER OF FIGURES \\
\hline 49 & 6 \\
\hline
\end{tabular}

(C) The author(s) 2022. This publication is an open access article. 


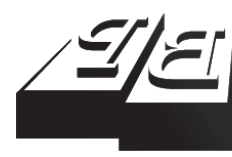

\section{BUSINESS PERSPECTIVES}

(O)

LLC "CPC "Business Perspectives" Hryhorii Skovoroda lane, 10, Sumy, 40022, Ukraine www.businessperspectives.org

Received on: $10^{\text {th }}$ of November, 2021 Accepted on: $25^{\text {th }}$ of January, 2022 Published on: $8^{\text {th }}$ of February, 2022

(c) Khalid M. Alomari, 2022

Khalid M. Alomari, Assistant Prof., Business Department, Faculty of Economics and Business Administration, Al-Hussein Bin Talal University, Jordan.
This is an Open Access article, distributed under the terms of the Creative Commons Attribution 4.0 International license, which permits unrestricted re-use, distribution, and reproduction in any medium, provided the original work is properly cited.

Conflict of interest statement: Author(s) reported no conflict of interest

Khalid M. Alomari (Jordan)

\title{
INFORMATION TECHNOLOGY PRACTICES IN THE JORDANIAN RETAIL SECTOR: EMPLOYEE AND CUSTOMER PERSPECTIVE
}

\begin{abstract}
This paper aims to discuss the adoption of information technology by retailers in Jordan and the impact on retail space, particularly in major urban areas of Jordan. Retailers such as Walmart, Amazon, and Metro are using advanced technologies to continue attracting and expanding consumers with the advent of internet of things (IoT), radio frequency identification (RFID) and point of sales (POS) hardware and software and retail.

The study relied on the explanatory approach to achieve these objectives. The study sample consisted of 134 stores that were chosen randomly and 480 customers of these stores, which were also chosen randomly. A questionnaire was designed based on previous studies and distributed among the respondents. The statistical analysis program (SPSS) was used to analyze the data obtained from the sample and test the hypotheses.

The study results showed that information technologies influence customer perceptions. However, RFID appears to have no impact on employee perception. Retailers' attitudes and adoption of information technologies in the Jordanian retail sector are heavily influenced by external factors. RFID usage does not play a significant role in determining the retailers' attitude towards adopting IT practices. The reason for such an outcome may be that sometimes the devices fail to read the various codes, and thus, it makes it difficult for the retailer to scan the products.
\end{abstract}

Keywords

JEL Classification

\section{INTRODUCTION}

Information technologies offer robust goods, quick and reliable results, and at a cost low enough to affect the sale rate. E-commerce is a valuable way to market something to customers. The use of e-commerce will increase customer demand and retailers' income as well. It is believed that the Internet is not a medium of dissemination that will produce significant growth. However, there will be an influence on the invention of information technologies by retailers. Retailers use the Internet to handle their promotion, correspondence, financial preparation, and administration needs. E-services overshadow current shortcomings in marketing services and build possibilities for marketing services (Rahman, 2004). According to Alshaketheepet al. (2020), e-services offer marketer of services an incredible degree of market influence. The rising availability of the Internet would improve the customer buying experience.

Earlier it was almost unheard of ways to obtain the monthly sales estimates within minutes. While technologies did not make the buying process more accessible, they encouraged the customers to maximize 
their activity efficiency by removing labor-intensive and repetitive activities. As a result, buyers are changing the current industry to implement emerging technology to meet and anticipate consumer needs (Fiorito \& Gable, 2011). This paper aims to analyze the impact of newly adopted technologies on employees and consumers.

Alomari et al. (2020) defines retail as the last stage of any commercial company. Communication technologies play a significant part in contemporary retailing. Retail executives consume a vast amount of information relevant to their business processes every day. It is impossible to keep up with the speed of innovation without modern technologies. The most prominent application of information technologies in the retail industry is POS (point of sale) and RFID.

Companies can now profit from the creativity and ideas of their customers using social media platforms. They have a considerable impact on Web 3.0 co-creation activities.

\section{LITERATURE REVIEW AND HYPOTHESES}

According to Alomari et al. (2020), retail is the last stage of any enterprise, which is very important in the world economy and plays a significant role. Retailing is a joint sale of companies from diverse industries that sell finished goods to the end customers. One of the most critical external considerations when developing a retail sector is technology and creativity (Segetlija, 2006). There are many changes to the industry due to the recent advancements in technologies (Deloitte, 2014).

The growth of information technologies in retail property, particularly in urban areas, has a significant impact on retail property in Malaysia (Najib et al., 2014). Retail Asia Online (2014) has written that to compete in the industry, retailers must transform their activities by upgrading their technologies. To earn a higher income, Malaysian retailers are turning to computer technologies.

Any of the convenience store owners are the early adopters of ICT schemes. Many organizations have updated their IT system to be eligible to register for the GST as the new system goes into force on April 1, 2015 (Retail Asia Online, 2014). Retail chains ought to consider the needs of their customers as much as possible.

IT will not only help supermarkets to cut their costs but also decrease their original IT costs. Two trends of business IT have been described in the retail context (Cho \& Fiorito, 2010). First, major supermarket stores have been able to develop their capabilities to fulfill the new expectations of customers and maximize their operating efficiency to reveal hidden needs (Cho \& Fiorito, 2010). Second, IT makes it possible for the supermarket chain to use a standard strategy when handling. Their aim is to increase their knowledge of customers, understand latent demand, and anticipate new demand channels. Previously it was shown that IT promotes the detection of secret consumer needs, thereby improving income (Renko \& Druzijanic, 2014). Alomari et al. (2020) show that the use of IT would increase economic value. Second, supermarkets use ICT to increase sales by gathering new customers and creating a network. Retail store owners can take advantage of online platforms to boost sales (Fleisher et al., 2004). Proper marketing needs to be introduced if a chain needs to maximize its revenue (Zhang \& Wedel, 2009). Past studies regarding IT consumption have not examined the link between IT usage and retail chain benefits by standardization of pricing and marketing strategies.

Big-box retailers who recognize market desires and adopt multiple strategies to meet those needs will acquire a reputation for originality that will prove vital for success (Markides \& Sosa, 2013). Exploration without digging is pointless (Herhausen, 2016). The benefit of expansion is based on the capacity to extract capital (Cao et al., 2009). IT in supermarket chains is no longer a valuable method for exploitation. Surveys suggest that both modes of information technology have significantly decreased the financial uncertainty in the retail market (Aloysius et al., 2016). However, the mechanism by which these innova- 
tions affect price setting and marketing is not very well known and not very well understood.

Many visitors come to New York City just four to six times a year to see the items that are being displayed. Fashion show customers will attend the runway shows and red-carpet activities.

Representatives must appear in person and transmit orders so that regulations can be set up accordingly (Dodes, 2007). Due to the increasing cost of transportation, shoppers may have to focus on emerging technologies to buy goods. Online shopping is getting more and more critical in the world when it comes to engaging designers and manufacturers with respect to the goods they sell. Consumers can try things at any time of the day from shopping venues like e-showrooms. While the purchasers cannot directly feel the fabric, complete product details and visual images are available to assist in purchasing selection. Online retails are more accessible than buying an item in person because they eliminate driving and shipping expenses. Fashion is evolving enormously because of emerging technology, such as social networking, which is now more relevant than ever before. Social networking aims to structure and provide a single entry point for contact and socialization. Smith (2010) suggested that social media officially adopted the "fad" logo. It was shown that Twitter had risen by $1,300 \%$ in that year. Social networking vehicles include Facebook, forums, and Twitter. Previously, there were performance evaluations for the items by list. In addition, social networking has transformed how the press spreads knowledge, with posts appearing during fashion shows online (Binkley, 2009).

People are now able to make choices based on customer preferences. The same refers to brand and customer sensitivities that often need to be considered when assessing a brand portfolio. In addition, food sources and their users respond immediately on websites such as Twitter and blogs. Instead of contacting market consulting companies to collect insights on markets, users can navigate blogs or Twitter to publicize product consistency issues. Aspects are typically named by names both accurate and measurable. The designer has applied various features to carry out and develop the applied research being undertaken. Busacca and Padula
(2005) suggest that it is helpful to classify states' characteristics into three distinct classes. Some specific attributes and considerations should be made when selling to customers. These standards are the minimum requirements for getting into the marketplace, but it is not a single foundation for customer loyalty. Transient properties positively or adversely affect others depending on the cause and circumstances.

\subsection{Retail sector in Jordan}

Consumers wanted expensive products, but they needed them to be highly affordable. These models would demonstrate the best style, size, and capability to substitute unsatisfactory goods. A secondary function with more minor but still essential determinants was developed. Buyers are aiming for both profitability as well as recurring fees. They hope that labeled products are accessible, readily obtained, and have readable labels and tags. The above conditions are more important than being close to home, easier to buy, having e-commerce arrangements, or being around for parking. This sector would benefit from strengthening the government's economic policies because of Jordan's membership in the World Trade Organization (WTO).

There are a variety of small enterprises, family-run ventures, and markets in Jordan. The construction of shopping centers and malls had a reorganization of shopping practices. Safeway supermarket encourages customers to go to supermarkets to purchase more than one thing in one location. The direct impact on the neighbor shops is excellent. Shopping in the mall is becoming a fun recreational activity for Jordanian shoppers. Jordan has become popular in shopping and the catering industry.

The delivery program is designed to satisfy the demands of the public. Malls and supermarkets provide playgrounds and other facilities for young people. Traders are marketing their wares from various outlets. The sales of alcohol are limited to licensed vendors and wholesalers. The big size and the importance of this market make it essential to research the characteristics of the customer behavior. Al-Tae'e (2002) addressed the factors which impacted the selection of restaurants in 
Amman. It was acknowledged that preferences had the most significant impact on decision-making, economic, and behavioral theories. According to the findings, consumer preferences significantly impact restaurant attributes such as interior decor, presentation, and cooking style. In addition, subjective standards strongly affected the intention to buy environmentally friendly products, influencing the actual purchasing behavior.

However, views toward the environment had no substantial impact on ecological purchase intentions (Nejati et al., 2011). Busacca and Padula (2005) analyzed the purchasing habits of high and middle-income Jordanians. They noticed significant variations between the purchasing patterns of the households in the high-income range and those of the low-income community. This contrast did not mean that one store was better than another was. A survey on the general prevalence of the elderly in Jordan found that about 49 percent of respondents are shopping every day. The study recommended convenience stores as the best way to access these consumers because customers can quickly reach these stores.

The retail industry in Jordan has been very dynamic, both vertically and horizontally. There are four stores of the Nationwide C-town chain. Since Carrefour (French) operated two supermarkets in Amman in 2007, others have opened. Abbadi Retail, a local grocery store in Amman, has increased its store size from 350,000 square feet to 500,000 square feet. With a gross area of 2,600 square meters, Al-Farid is improving its goal by creating new networks. The size of $\mathrm{Al}$ Mukhtar is 3,000 square meters. On the ground floor, demand for household and kitchen products is growing. It will be sold in specialist retail stores instead of supermarkets or general stores. Business is much more dependent on neighborhood shops in Amman, except for last-minute food requirements. Supermarkets are everywhere in Jordan, particularly outside of Amman. This behavior makes it difficult for retailers to stay financially secure and stable. Some stores introduce seasonal sales and exclusive product ranges to keep their consumers up-to-date and invite new users. Only Amman's broad supermarkets are famous for home delivery (Khaled et al., 2019; Khaled et al., 2020a, 2020b).

\subsection{Hypotheses}

This study is going to test the following research hypotheses:

\section{$H_{0} 1$ : There is no significant impact of consumer attributes on perception.}

$\mathrm{H}_{0}$ 2: There is no significant impact of subjective norms on perception.
$H_{0}$ 3: There is no significant impact of perceived usefulness on perception.
$H_{0} 4$ : There is no significant impact of perceived ease of use on perception.
$H_{0}$ 5: There is no significant impact of RFID usage on perception.

\section{METHODOLOGY}

The study aims to find out the benifits of retailer adoption of information technology solutions in the Jordanian retail market. A research design is a comprehensive outline for collecting and reviewing data and knowledge based on the research questions and objectives. The study goals would decide the research design that must be chosen. Studies that determine the cause-and-effect relationship between variables are said to be causal studies (Saunders et al., 2007). According to Lancaster (1966), attitude drives the consumers' utility or attributes. Ajzen (1991) defines that attitude towards the behavior as the degree to which a person has a favorable or unfavorable evaluation or appraisal of the behavior in question. Keen et al. (2004) suggest that attitude is determined by the individual's evaluations of the outcomes and an assessment of how likely the outcome is to occur.

Davis et al. (1989) propose perceived ease of use in the RFID. It is the degree to which a person believes that using a particular system would be free of effort. Keen et al. (2004) note that the ease of use significantly influences first-time trials and, respectively, the consumer to use the technology again.

Explanatory research was selected for this subject. In addition, this study explores cause and effect in- 
teractions. Finally, the explanatory analysis aims to clarify the relationships between factors and analyze a particular scenario or a research issue.

The key aim of this analysis is to discover the impact that retail has on the economy. It would favor the supermarket industry because of recent technological advances. This study has been performed to examine the marketing advantages of information technologies among Jordanian retail firms, identify problems and challenges encountered by retailers when introducing IoT solutions, and assess the customer loyalty of the customers using IoT in the retail industry.

Data sources include both primary and secondary sources. The main source contains the views of the senior executives of the retail stores involved and the consumers visiting the retail stores. Secondary references include surveys, regular textbooks, journals, magazines, blogs, and newspapers.

The community is made up of retail stores operating in Jordan. The sample system has been planned to confine samples in Amman. Although the Jordanian retail sector has most retail stores in the unorganized sector, the technology application in organized retailing has been found significant. The sampling system was then limited to retail stores with different modern product types. 150 stores for data processing have been randomly chosen. However, only 134 shops replied to the survey. Visitors to the shop had to calculate customer loyalty. The replies from the customers who visited the shops were gathered simultaneously with feedback from the store employees. Consequently, consumer comments have been obtained by non-probabilistic and intentional sampling. A total of 480 customer comments were received.

The primary component analysis using Varimax rotation was conducted on several item constructs to validate the instrument and its constructs. Next, the advantage factors have been evaluated Table 1 lists the unrotated key part extraction and Varimax rotated matrix. The sample adequacy value for Kaiser-Meyer-Olkin was found to be 0.959 . Bartlett's sphericity test also reveals that the causes are clarified correctly by things at 0.000 . In addition, the instrument's convergent validity (items representing the structure and no cross-load) and the discriminant validity (the constructions derived are distinct from other constructions) can be viewed as acceptable.

Table 1. KMO results

\begin{tabular}{|c|c|c|}
\hline \multicolumn{3}{|c|}{ KMO and Bartlett's test } \\
\hline \multicolumn{2}{|c|}{ Kaiser-Meyer-Olkin Measure of Sampling Adequacy } & 0.959 \\
\hline \multirow{3}{*}{$\begin{array}{l}\text { Bartlett's Test of } \\
\text { Sphericity }\end{array}$} & Approx. Chi-Square & 3603.89 \\
\hline & Df & 170 \\
\hline & Sig. & 0.000 \\
\hline
\end{tabular}

Both structures have Cronbach's alpha values above the minimum appropriate value of 0.7 (Table 2). Except for technical problems, all other systems had a value above 0.9 and a rather good internal quality. However, the Cronbach's alpha rating of technological problems (0.88) is approximately 0.9 , meaning a strong internal quality. The instrument is thus considered accurate.

Table 2. Reliability

\begin{tabular}{l|c|c}
\hline \multicolumn{1}{c|}{ Constructs } & $\begin{array}{c}\text { Number of } \\
\text { items }\end{array}$ & $\begin{array}{c}\text { Cronbach's } \\
\text { alpha }\end{array}$ \\
\hline $\begin{array}{l}\text { Consumer/Retailer } \\
\text { Attributes }\end{array}$ & 9 & 0.910 \\
\hdashline Subjective Norms & 5 & 0.921 \\
\hline Perceived Usefulness & 4 & 0.911 \\
\hline Perceived Ease of Use & 6 & 0.912 \\
\hline RFID Usage & 4 & 0.910 \\
\hline
\end{tabular}

\section{DATA ANALYSIS}

\subsection{Employee profile}

The demographics of the respondents are seen in Table 3. Answers were collected from 134 stores throughout Jordan's metropolitan cities. 70 stores had an individual retailer, which accounted for $52.3 \%$ of all respondents. Chain stores accounted for 64 stores representing $47.7 \%$ of overall respondents. On the shop's judgement system, 70 shops $(52.2 \%)$ of total respondent stores made individual organizational and acquisition decisions. This will comprise primarily small shops. Almost $28.8 \%$ of respondents had decentralized decision-making, and $14.9 \%$ had centralized decision-making. Almost 4.1\% of the stores had a hierarchical and dispersed decision-making blend. 
Table 3. Employee profile

\begin{tabular}{|c|c|c|c|c|}
\hline \multicolumn{2}{|c|}{ Sample characteristics } & \multirow{2}{*}{$\frac{\text { Number of employees }}{70}$} & \multirow{2}{*}{ Proportion } & \multirow{2}{*}{$\begin{array}{c}\text { Percentage } \\
52.20 \%\end{array}$} \\
\hline Tuno of pronorty & Individual & & & \\
\hline туре оा ріорет су & Chain store & 64 & 0.477 & $47.70 \%$ \\
\hline \multirow{4}{*}{ Type of decisions } & Individual & 70 & 0.522 & $52.20 \%$ \\
\hline & Centralized & 39 & 0.288 & $28.80 \%$ \\
\hline & Decentralized & 20 & 0.149 & $14.90 \%$ \\
\hline & Dispersed blend & 5 & 0.041 & $4.10 \%$ \\
\hline \multirow{7}{*}{ Type of commodity } & Grocery and food & 10 & 0.074 & $7.40 \%$ \\
\hline & Jewelry & 12 & 0.089 & $8.90 \%$ \\
\hline & Household & 20 & 0.149 & $14.90 \%$ \\
\hline & Apparel & 47 & 0.351 & $35.10 \%$ \\
\hline & Electronic & 15 & 0.114 & $11.40 \%$ \\
\hline & Footwear & 14 & 0.104 & $10.40 \%$ \\
\hline & Remaining & 16 & 0.119 & $11.90 \%$ \\
\hline
\end{tabular}

Responses from stores working in different commodity types have been obtained. $7.4 \%$ of shops were grocery and food shops, while $8.9 \%$ of comments were from golden jewelry shops. Household durable stores accounted for $14.9 \%$ of the respondents and apparel shops $-35.1 \%$. Electronic stores got $18.8 \%$ of the responses. Footwear stores accounted for nearly $10.4 \%$ and the remaining $11.9 \%$ for other types. Thus, organized retail shops are primarily clothes and household goods stores. There is a moderate presence of food/grocery, computer retailers, and footwear stores. Stores of gold jewelry are limited.

\subsection{Customer profile}

Table 4 shows the customer profile, a total of 480 answers have been received. Of these, 229 answers were obtained from men, approximately $47.7 \%$ of the sample. On the other hand, 251 reactions were received from women, comprising $52.3 \%$ of the overall sample. A survey of the marital status of the respondents involved 330 (68.7\%) married and 150 (31.3\%) single.

The majority of respondents (52.7\%) were graduates. $16.66 \%$ of them were still studying. $16.4 \%$ of all respondents were postgraduates, and 14.6\% had other training qualifications. The interviewees were also classified by their jobs. Many have been working personally, making up almost 30\% of the sample.

The findings in Table 5 show that most of the hypotheses suggested in this study are supported. The first hypothesis shows a direct impact of customers attributes on retailer behavior $(\beta=0.512$, $p=.000) . \beta$ value $=0.512$ indicates that customers attributes affect the dependent variable of retailer perception by $51.2 \%$. Therefore, a one-unit increase in customers attributes will result in a $51.2 \%$ improvement in retailer perception.

Second hypothesis tests the impact of subjective norms on retailer behavior $(\beta=0.349, p=0.002)$. $\beta$ value $=0.349$ indicates that subjective norms affect the dependent variable of retailer perception by $34.9 \%$. Therefore, a one-unit increase in subjective norms will result in a $34.9 \%$ improvement in retailer perception.

The third hypothesis tests the impact of perceived usefulness on retailer perception; it was supported

Table 4. Customer profile

\begin{tabular}{|c|c|c|c|c|}
\hline \multicolumn{2}{|c|}{ Sample characteristics } & \multirow{2}{*}{$\frac{\text { Number of employees }}{229}$} & \multirow{2}{*}{$\frac{\text { Proportion }}{0.477}$} & \multirow{2}{*}{$\begin{array}{c}\text { Percentage } \\
47.70 \%\end{array}$} \\
\hline Gender & Male & & & \\
\hline Gernuer & Female & 251 & 0.523 & $52.30 \%$ \\
\hline \multirow{2}{*}{ Marital status } & Married & 330 & 0.687 & $68.70 \%$ \\
\hline & Single & 150 & 0.313 & $31.30 \%$ \\
\hline \multirow{4}{*}{ Education level } & Graduate & 20 & 0.527 & $52.70 \%$ \\
\hline & Studying & 5 & 0.166 & $16.60 \%$ \\
\hline & Post graduate & 10 & 0.164 & $16.40 \%$ \\
\hline & Training courses & 12 & 0.146 & $14.60 \%$ \\
\hline
\end{tabular}


Table 5. Hypotheses testing (dependent variable - retailer perception)

\begin{tabular}{|c|c|c|c|c|c|}
\hline S. No & Independent variable & Dependent variable & Coefficient & Sig & Result \\
\hline 1 & Consumer/Retailer Attributes & \multirow{5}{*}{ Retailer Perception } & 0.512 & 0.000 & Significant \\
\hline 2 & Subjective Norms & & 0.349 & 0.002 & Significant \\
\hline 3 & Perceived Usefulness & & 0.687 & 0.000 & Significant \\
\hline 4 & Perceived Ease of Use & & 0.502 & 0.000 & Significant \\
\hline 5 & RFID Usage & & 0.041 & 0.318 & No significance \\
\hline
\end{tabular}

Table 6. Hypotheses testing (dependent variable - consumer perception)

\begin{tabular}{|c|c|c|c|c|c|}
\hline S. No & Independent variable & Dependent variable & Coefficient & Sig & Result \\
\hline 1 & Consumer/Retailer Attributes & \multirow{5}{*}{ Consumer Perception } & 0.02 & 0.032 & accepted \\
\hline 2 & Subjective Norms & & 0.115 & 0.016 & accepted \\
\hline 3 & Perceived Usefulness & & 0.349 & 0.000 & accepted \\
\hline 4 & Perceived Ease of Use & & 0.600 & 0.000 & accepted \\
\hline 5 & RFID Usage & & 0.101 & 0.006 & accepted \\
\hline
\end{tabular}

$(\beta=0.687, p=0.000) . \beta$ value $=0.687$ indicates that attitude towards technology affects the dependent variable of retailer perception by $68.7 \%$. Therefore, a one-unit increase in perceived usefulness will result in a $68.7 \%$ improvement in retailer perception.

The fourth hypothesis tests the impact of perceived ease of use on retailer perception; it was supported $(\beta=0.502, p=0.000) . \beta$ value $=0.502$ indicates that perceived ease of use affects the dependent variable of retailer perception by $50.2 \%$. Therefore, a one-unit increase in perceived ease of use will result in a $50.2 \%$ improvement in retailer perception.

The fifth hypothesis, which tests the impact of RFID usage on retailer perception, was supported $(\beta=0.041, p=0.318)$. $\beta$ value $=0.041$ indicates that RFID usage affects the dependent variable of retailer perception by $4 \%$.

The findings in Table 6 show that all hypotheses suggested in this study are supported. The first hypothesis shows a direct impact of retailer attributes on consumer behavior $(\beta=0.02, p=0.030)$. $\beta$ value $=0.02$ indicates that retailer attributes affect the dependent variable of consumer perception by $2.0 \%$. Therefore, a one-unit increase in retailer attributes will result in a $2 \%$ improvement in consumer perception.

Second hypothesis tests the impact of subjective norms on consumer behavior $(\beta=0.115, p=.016)$. $\beta$ value $=0.115$ indicates that subjective norms affect the dependent variable of consumer perception by $11.5 \%$. Therefore, a one-unit increase in subjective norms will result in an $11.5 \%$ improvement in consumer perception.

The third hypothesis, which tests the impact of perceived usefulness on consumer perception, was supported $(\beta=0.349, \mathrm{p}=0.000)$. $\beta$ value $=0.349$ indicates that perceived usefulness affects the dependent variable of consumer perception by $34.9 \%$. Therefore, a one-unit increase in perceived usefulness will result in a $34.9 \%$ improvement in consumer perception.

The fourth hypothesis, which tests the impact of perceived ease of use on consumer perception, was supported $(\beta=0.600, p=0.000)$. $\beta$ value $=0.600$ indicates that perceived ease of use affects the dependent variable of consumer perception by $60.0 \%$. Therefore, a one-unit increase in perceived ease of use will result in a $60.0 \%$ improvement in consumer perception.

The fifth hypothesis, which tests the impact of RFID usage on consumer perception, was supported $(\beta=0.101, p=0.006) . \beta$ value $=0.101$ indicates that RFID usage affects the dependent variable of consumer perception by $10.1 \%$. Therefore, a one-unit increase in RFID usage will result in a $10.1 \%$ improvement in consumer perception.

\section{DISCUSSION}

The study results showed a statistically significant impact of information technology practices in all 
dimensions represented by consumer/retailer attributes, subjective norms, perceived usefulness, perceived ease of use, and RFID usage on the retailer and consumer perceptions.

On the customer side, the study attributes this finding to the fact that one of the essential technological impacts is the ability to make payments digitally. This possibility has empowered clients to an unimaginable extent. Until a few years ago, it was noted that debit and credit cards were effective. However, the development of technology in this regard did not end there. Instead, it offered a better solution, as the multidimensional features available on smartphones enabled customers to filter payments more efficiently. Today, it is considered the most preferred method of payment. In addition, they are proven to be more effective than debit and credit cards.

Customers perceive the overall enjoyment of the buying experience as most important in their purchasing decision. Moreover, in the entire buying process, payment plays an important role. The ease of mobile payments adds to a better customer experience. Technology is already having a considerable impact on customer experience.

The significant technological impact was in the field of communications. The way technology has enhanced communications is enormous. Business is not just about creating customers, but their main concern is maintaining the relationship with them. One of the critical aspects contributing to such a good relationship is communication.

This result agreed with the results of Abu Rumman (2003), Al-Lamy et al. (2018), and Busacca and Padula
(2005), who showed an important effect of information technology practices on consumer perception.

As for the retailer perception, knowing customer requirements has become much easier in the age of technology. In addition, the reactions have also become exposed to decision-makers and project owners, unlike in the past, when scholars used to do paper questionnaires and distribute them to know customer reactions. With the button push, retailers can know what a customer is looking for without effort or time.

With the impressive technological development that the world has witnessed in recent times, one cannot hide the impact of modern technology on the performance of organizations and companies. These advanced technological industries have carried the character of innovation, development, and flexibility in dealing. This development has helped many companies and organizations to manage various departments at multiple levels. However, most companies have built their management strategies on information technology to the extent that every organization lags behind this massive development. After some time, one will notice that it has begun to decline at all levels, especially in terms of quality and marketing. Thus, eliminating the need to know how to use this technology to achieve the desired goals.lativ si

This result agreed with Khaled et al. (2020b) and Sabu and Chandra (2018), who showed the benefits of information technology practices on increasing the efficiency and effectiveness of business organizations in general.

\section{CONCLUSION}

This study aimed to identify the factors that affect the ability of Jordanian retailers to use information technology in the retail sector in Jordan. The results showed a significant positive relationship between the independent and dependent variables in this model, as shown in this analysis.

Based on the study results, many factors can affect consumers and retailers. Technology plays an essential role in the advancement of the industry. The competitive environment also affects retailers' abandoning old technologies due to inflation and technological advancement.

Jordan's retail industry can implement both ideas. These external factors strongly influence the attitudes of retailers and the adoption of information technology in the Jordanian retail sector. As all fac- 
tors influence consumer perception and retailers except in the case of retailer perception, RFID usage has not played a significant role in determining retailers' attitudes towards technology adoption. The reason may be that the devices sometimes fail to read the different codes, and thus it is difficult for the retailer to scan the products, and eventually, they have to write the products, which causes hassles and delays in billing.

\section{LIMITATIONS}

Respondents are entitled to opt not to provide details for procedural purposes. Upon request, the company will not disclose the strategic details. In data collection, self-administered questionnaires have a detrimental impact on the efficacy. There may be a sampling error in certain places where the randomized sampling system is used. It is more likely that the chance to purchase cigars and cigarettes at a store will be more limited.

\section{AUTHOR CONTRIBUTIONS}

Conceptualization: Khalid M. Alomari.

Data curation: Khalid M. Alomari.

Formal analysis: Khalid M. Alomari.

Funding acquisition: Khalid M. Alomari.

Investigation: Khalid M. Alomari.

Methodology: Khalid M. Alomari.

Project administration: Khalid M. Alomari.

Resources: Khalid M. Alomari.

Software: Khalid M. Alomari.

Supervision: Khalid M. Alomari.

Validation: Khalid M. Alomari.

Visualization: Khalid M. Alomari.

Writing - original draft: Khalid M. Alomari.

Writing - review \& editing: Khalid M. Alomari.

\section{ACKNOWLEDGMENT}

This paper is supported with a generous fund of the faculty of scientific research and graduate studies, Al-Hussein Bin Talal University. Fund decision number - 47/2021.

\section{REFERENCES}

1. Abu Rumman, A. (2003).

Evaluation of Jordanian consumer attitude towards Departmental stores. Jordan Journal of Applied Science, 6(1), 69-95.

2. Ajzen, I. (1991). The theory of planned behavior. Organizational Behavior and Human Decision Processes, 50(2), 179-211. https://doi.org/10.1016/07495978(91)90020-T

3. Al-Lamy, H. A., Bakry, M. H., Raad, W., Al-Shami, S. A.,
Alaraji, Z.J., Alsa-Lihi, M. W., \& Al-Tameemi, H. M. (2018). Information technology infrastructure and small medium enterprises' in Iraq. Opcion, 34(86), 1711-1724. Retrieved from https://www.researchgate.net/ profile/Hayder-Al-Lamy/publication/332556640_INFORMATION_ TECHNOLOGY_INFRASTRUCTURE_AND_SMALL_MEDIUM_ENTERPRISES_IN_IRAQ/ links/5cbda0714585156cd7a91aac/ INFORMATION-TECHNOLO-
GY-INFRASTRUCTURE-ANDSMALL-MEDIUM-ENTERPRISES-IN-IRAQ.pdf

4. Al-Tae'e, H. (2002). Factors Influencing Food Preference Decision of Restaurant Clients. Dirasat for Management Science, 29(2).

5. Alomari, K. M., Mansour, A. M., Almohtaseb, A. A., Salah, A. A., \& Alshaketheep, K. M. (2020). Lean Six Sigma in Jordanian Organizations. International 
Journal of Economics \& Business Administration (IJEBA), 8(3), 429-447. https://doi. org/10.37394/23207.2020.17.79

6. Aloysius J. A., Hoehle H., Venkatesh V. (2016). Exploiting big data for customer and retailer benefits: A study of emerging mobile checkout scenarios. International Journal of Operations \& Production Management, 36(4), 467-486.

7. Alshaketheep, K. M. K. I., Salah, A. A., Alomari, K. M., Khaled, A. S. D., \& Jray, A. A. A. (2020). Digital Marketing during COVID-19: Consumers' Perspective. WSEAS Transactions on Business and Economics, 17, 831-841. https://doi. org/10.37394/23207.2020.17.81

8. Ameed, S. S., \& Kumar, D. (2015). Impact Of Membership Card On Retention Of Customers In Retail Sector In Chennai. International Journal of Management, 6(1), 443-455.

9. Binkley, S. (2009). The civilizing brand: shifting shame thresholds and the dissemination of consumer lifestyles. European Journal of Cultural Studies, 12(1), 21-39. https://doi. org/10.1177/1367549408098703

10. Bishnoi, V. (2014). Role of Information Technology and ECRM in 21st Century Retail Organisations. International Journal of Emerging Techonology and Advanced Engineering, 4(1), 433-440.

11. Busacca, B., \& Padula, G. (2005). Understanding the relationship between attribute performance and overall satisfaction: Theory, measurement and implications. Marketing Intelligence \& Planning, 23(6), 543-561. http://dx.doi. org/10.1108/02634500510624110

12. Cao, Q., Gedajlovic, E., \& Zhang, H. (2009). Unpacking Organizational Ambidexterity: Dimensions, Contingencies, and Synergistic Effects. Organization Science, 20(4), 781-796. https://doi. org/10.1287/orsc.1090.0426

13. Chang, T.-H., Fu, H.-P., Lee, W.-I., Lin, Y., \& Hsueh, H.-C. (2007). A study of an augmented CPFR model for the $3 \mathrm{C}$ retail industry. Supply Chain Management, 12(3), 200-209. https://doi. org/10.1108/13598540710742518

14. Cho, H., \& Fiorito, S. S. (2010). Self-Service Technology in Retailing. The Case of Retail Kiosks. Symphonya. Emerging Issues in Management, 1, 43-55. https://doi. org/10.4468/2010.1.05cho.fiorito

15. Davis, F. D., Bagozzi, R. P., \& Warshaw, P. R. (1989). User acceptance of computer technology: A comparison of two theoretical models. Management Science, 35(8), 982-1003. http:// dx.doi.org/10.1287/mnsc.35.8.982

16. Deloitte. (2014). Global Powers of Retailing 2014: Retail Beyond begins. Retrieved from https:// www2.deloitte.com/content/dam/ Deloitte/global/Documents/Consumer-Business/dttl_CB_GlobalPowers-of-Retailing-2014.pdf

17. Deloitte. (2016). Technology in Retail: From centre stage to supporting player: Beyond four walls. Retrieved from https:// www2.deloitte.com/content/dam/ Deloitte/au/Documents/consumer-industrial-products/deloitte-aucip-retail-trends-technology-inretail-240816.pdf

18. Dodes, R. (2007, February 3). Strike a pose, count your pennies. The Wall Street Journal. Retrieved from https://www.wsj.com/articles/SB117047280883797124

19. Earl, M.J. (1993). Experiences in strategic information systems planning: editor's comments. MIS Quarterly, 17(3), 2-3. Retrieved from https://www.proquest.com/ docview/218116307

20. Eide, B. (2013). Consumer Behavior Theories - Purchasing Organic Food (Thesis). Aarhus University. Retrieved from https:// www.academia.edu/8020018/Consumer_Behavior_Theories_Purchasing_Organic_Food

21. Fleisher, C. S., \& Bensoussan, B. (2004). Strategic and Competitive Analysis: Methods and Techniques for Analysing Business Competition. London: Prentice-Hall.
22. Fiorito, S. S., \& Gable, M. (2011). Retail Buying Practices and Policies in a Global Economy. Columbus, OH: Prentice-Hall.

23. Hair, J. F., Anderson, R. E., Tatham, R. L., \& Black, W. C. (1995). Multivariate Data Analysis. New York: Simon and Schuster.

24. Herhausen, D. (2016). Unfolding the ambidextrous effects of proactive and responsive market orientation. Journal of Business Research, 69(7), 25852593. https://doi.org/10.1016/j. jbusres.2015.10.139

25. Khaled, A. S. D., Alabsy, N. M., Al-Homaidi, E. A., \& Saeed, A. M. M. (2020a). The Impact Of The Covid-19 Pandemic On Retailer Performance: Empirical Evidence From India. Innovative Marketing, 16(4), 129-138. http://dx.doi. org/10.21511/im.16(4).2020.11

26. Khaled, A. S., Ahmed, S., Tabash, M. I., Al-Homaidi, E. A., \& Hossain, M. I. (2019). The Impact of Technological and Marketing Innovations on Retailing Industry: Evidence of India. Journal of Reviews on Global Economics, 8, 948-957. https://doi. org/10.6000/1929-7092.2019.08.81

27. Khaled, A. S., Ahmed, S., Yahya, A. T., \& Farhan, N. H. (2020b). The role of innovation on Indian retail industry. International Journal of Business Innovation and Research, 23(4), 435-452. https:// www.inderscienceonline.com/doi/ abs/10.1504/IJBIR.2020.111793

28. Keen, C., Wetzels, M., \& de Ruyter, K., Feinberg, R. (2004). E-retailers versus retailers: Which factors determine consumer preferences. Journal of Business Research, Elsevier, 57(7), 685-695.

29. Lancaster, K. J. (1996). A new approach to consumer theory. Journal of Political Economics, 74(2), 132-157.

30. Markides, C., \& Sosa, L. (2013). Pioneering and first mover advantages: The importance of business models. Long Range Planning, 46, 325-340.

31. Moghadamzadeh, A., Ebrahimi, P., Radfard, S., Salamzadeh, A., \& Khajeheian, D. (2020). 
Investigating the role of customer co-creation behavior on social media platforms in rendering innovative services. Sustainability, 12(17), 6926. https://doi. org/10.3390/su12176926

32. Nair, S. K., \& Nair, B. C. (2018). Key Drivers \& Factors Influencing Organized Retail Sector in Kerala. International Journal of Mechanical Engineering and Technology, 9(6), 680-684. Retrieved from https://iaeme.com/ MasterAdmin/Journal_uploads/ IJMET/VOLUME_9_ISSUE_6/ IJMET_09_06_077.pdf

33. Najib, M., Dewi, F. R., \& Widyastuti, H. (2014). Collaborative networks as a source of innovation and sustainable competitiveness for small and medium food processing enterprises in Indonesia. International Journal of Business and Management, 9(9), 147.

34. Nejati, M., Salamzadeh, Y., \& Salamzadeh, A. (2011). Ecological purchase behaviour: insights from a Middle Eastern country. International Journal of Environment and Sustainable Development, 10(4), 417-432. Retrieved from https://papers.ssrn. com/sol3/papers.cfm?abstract_ $\mathrm{id}=2042714$

35. Rahman, Z. (2004). Welcome Note. India Quarterly. 60(4), 1-2. https://doi. org/10.1177/097492840406000401

36. Renko, S., \& Druzijanic, M. (2014). Perceived usefulness of innovative technology in retailing: Consumers and retailers point of view. Journal of Retailing and Consumer Services, 21(5), 836-843.

37. Retail Asia Online. (2014). Home. Retrieved from https://retailasia. net/

38. RFID. (2010). The RFID industry daily. Retrieved from https://www. printedelectronicsworld.com/articles/1961/printed-rfid-in-2010

39. Salomann, H., Dous, M., Kolbe, L., \& Brenner, W. (2006). Advancing CRM initiatives with knowledge management. Journal of Information Science and Technology, 3(2), 24-44. Retrieved from https://citeseerx.ist.psu.edu/ viewdoc/download?doi=10.1.1.59 7.1661\&rep $=$ rep $1 \&$ type $=$ pdf

40. Sanders, N. R. (2008). Pattern of information technology use: the impact on buyer-suppler coordination and performance. Journal of Operations Management, 26(3), 349-367.

41. Saunders, M. N. K., Lewis, P., \& Thornhill, A. (2007). Research methods for business students. Harlow, England: Financial Times/ Prentice Hall.

42. Segetlija, Z. (2009). Contemporary Management Development Of Retail Trade. Ekonomski vjesnik, XXII(1), 87-92. Retrieved from https://hrcak.srce.hr/42862

43. Shet, A. R. (2016). Information Technology in Retail Sector. International Journal of Scientific Engineering and Research (IJSER), 4(5), 43-46. Retrieved from https://www.ijser.in/archives/v4i5/ IJSER15814.pdf

44. Smith, S. (2010). Network booster. Stores Magazine, 92(3), 30.

45. Steermann, H. (2003). A practical look at CPFR: the Sears-Michelin experience. Supply Chain Management Review, 7(4), 46-53. Retrieved from https://trid.trb. org/view/606662

46. The Star. (2013, October 26). Budget 2014: GST at 6\% from April 2015. Retrieved from https://www.thestar.com.my/ news/nation/2013/10/26/gst-at6-from-april-2015-najib-salesand-services-taxes-will-be-replaced-by-a-single-tax/

47. Ward, P., \& Zhou, H. (2006). Impact of information technology integration and lean/just-in-time practices and lead-time performance. Decision Sciences, 37(2), 177-203. https://doi.org/10.1111/j.15405915.2006.00121.x

48. Weber, M. M., \& Kantamneni, S. P. (2002). POS and EDI in retailing; an examination of underlying benefits and barriers. Supply Chain Management, 7(5), 311-317. https://doi. org/10.1108/13598540210447755
49. Zhang, J., \& Wedel, M. (2009). The Effectiveness of Customized Promotions in Online and Offline Stores. Journal of Marketing Research, 46(2),190-206. https:// doi.org/10.1509/jmkr.46.2.190 